\title{
Evaluation of the Effect of NQ01 C609T (rs1800566) Gene Variations in Philadelphia-negative Myeloproliferative Neoplasms in Turkish Population
}

\section{Philadelphia-negatif Miyeloproliferatif Neoplazilerde NQ01 C609T (rs1800566) Gen Varyasyonlarının Etkisinin Türk Toplumunda Değerlendirilmesi}

\author{
(1) Ayşegül Başak Akadam Teker¹, (10 Aynur Dağlar Aday², (10 Hasan Dermenci³, (1) Ipek Yönal Hindilerden³, \\ (1) Hülya Yılmaz Aydoğan ${ }^{4}$, (1) Oğuz Öztürk4, (1) Akif Selim Yavuz ${ }^{3}$
}

\begin{abstract}
${ }^{1}$ Giresun University Faculty of Medicine, Department of Medical Genetic, Giresun, Turkey
2istanbul University İstanbul Faculty of Medicine, Department of Internal Medicine, Division of Medical Genetics, Istanbul, Turkey

3istanbul University İstanbul Faculty of Medicine, Department of Internal Medicine, Division of Hematology, İstanbul, Turkey

4 istanbul University Aziz Sancar Institute of Experimental Medicine, Department of Molecular Medicine, İstanbul, Turkey
\end{abstract}

\begin{abstract}
Introduction: Philadelphia-negative myeloproliferative neoplasm (MPN) is a hematopoietic stem cell disorder consisting of essential thrombocythemia (ET), polycythemia vera (PV), and primary myelofibrosis (PMF) associated with myeloid cell proliferation without differentiation and maturation defects. It is characterized by hypercellular bone marrow and an increase in one or more cell lines in the peripheral blood. In the hematopoietic stem cell, janus kinase 2 (JAK2), which is a cytoplasmic tyrosine kinase, remains constantly phosphorylated (active) as a result of the V617F somatic mutation in the pseudokinase region. Even if the phosphorylated JAK2 does not receive a stimulus, it performs signal transmission and causes continuous gene expression. This explains the excessive increase in one or more blood cell lines. $\mathrm{NAD}(\mathrm{P}) \mathrm{H}$ quinone oxidoreductase-1 (NQ01) is a phase 1 enzyme that prevents the formation of reactive and toxic semiquinone metabolites by reducing two electrons in one step. The C609T polymorphism of the NQ01 gene leads to loss of enzyme activity due to the enzyme becoming unstable. While enzyme activity is not observed in individuals with both mutant alleles, moderate activity is observed in heterozygous individuals. Studies have reported a relationship between NQ01 C609T polymorphism and various cancer types. In our study, it was aimed to investigate the possible relationship between NQ01 C609T polymorphism and MPN development.

Methods: Our study group consisted of 119 MPN patients and 122 healthy controls. DNA isolation was performed from peripheral blood taken from the study groups. The JAK2 V617F mutation was detected using Real-time polymerase chain reaction (PCR), and NQ01 C609T gene polymorphism was detected using the PCR- restriction fragment length
\end{abstract}

öz

Amaç: Philadelphia-negatif miyeloproliferatif neoplazi (MPN); farklılaşma ve olgunlaşma kusuru olmaksızın, miyeloid hücre çoğalması ile ilişkili esansiyel trombositemi (ET), polisitemi vera (PV) ve primer miyelofibrozisten (PMF) oluşan hematopoetik kök hücre bozukluğudur. Hipersellüler kemik iliği ve periferik kanda bir veya daha fazla hücre serisinin artması ile karakterizedir. Hematopoietik kök hücrede, sitoplazmik tirozin kinaz olan janus kinaz 2 (JAK2), psödokinaz bölgesindeki V617F somatik mutasyonunun bir sonucu olarak sürekli fosforile (aktif) kalır. Fosforile JAK2 bir uyarıcı almasa bile, sinyal iletimi gerçekleştirir ve sürekli gen ekspresyonuna neden olur. Bu durum bir veya daha fazla kan hücre serisinin aşırı artıșını açıklamaktadır. Nikotinamid adenin dinükleotid fosfat kinon oksidoredüktaz-1 (NQ01) tek basamakta iki elektron indirgenmesini sağlayarak reaktif ve toksik semikinon ara metabolitlerinin olușumunu engelleyen faz 1 enzimidir. NQ01 geninin C609T polimorfizmi, enzimin kararsız hale gelmesinden dolayı enzim aktivitesinin kaybına yol açar. Iki alleli de mutant olan bireylerde enzim aktivitesi görülmezken, heterozigot bireylerde orta düzeyde aktivite gözlenir. Yapılan çalışmalarda NQ01 C609T polimorfizmi ile çeșitli kanser tipleri arasında ilişki olduğu bildirilmiştir. Çalışmamızda NQ01 C609T polimorfizmi ile MPN gelişimi arasındaki olası ilișkinin araștırılması amaçlanmıştır.

Yöntemler: Çalıșma grubumuzu 119 MPN hastası ve 122 sağlıklı kontrol oluşturdu. Çalışma gruplarından alınan periferik kandan DNA izolasyonu yapıldı. Janus kinase 2 (JAK2) V617F mutasyonu gerçek zamanlı polimeraz zincir reaksiyonu (PZR), NQ01 C609T gen polimorfizmi PZR-sınırlayıCı enzim

Cite this article as/Atıf: Akadam Teker AB., Dağlar Aday A, Dermenci H, Yönal Hindilerden I, Yılmaz Aydoğan H, Öztürk 0, Yavuz AS. Evaluation of the Effect of NQ01 C609T (rs1800566) Gene Variations in Philadelphianegative Myeloproliferative Neoplasms in Turkish Population. İstanbul Med J 2020; 21(1): 7-12.

(c) Copyright 2020 by the Istanbul Training and Research Hospital/istanbul Medical Journal published by Galenos Publishing House.

(C) Telif Hakkı 2020 istanbul Ĕgitim ve Araștırma Hastanesi/Istanbul Tıp Dergisi, Galenos Yayınevi tarafından basılmıștır. 
polymorphism method. SPSS 21.0 was used for statistical analysis.

Results: No statistically significant difference was found between the patient and control groups in terms of NQ01 genotype distributions ( $p>0.05)$. When cases with ET, PMF, and PV were compared in terms of frequency of JAK2 V617F mutation, the rate in PV was higher (respectively; $62.5 \%, 61.5 \%$, $78.6 \%$ ). There was no relationship between JAK2 mutation positivity and $\mathrm{NQO} 1 * 2$ polymorphism.

Conclusion: According to the results obtained from our study, there is no relationship between $\mathrm{NQO1}^{*} 2$ polymorphism and MPN. Variants of the NQ01 enzyme, which is essential in detoxification and activation of procarcinogens, did not increase the formation of the JAK2 V617F mutation, which is common in MPN patients. It is thought that the results should be supported by increasing the number of patient and control groups.

Keywords: Myeloproliferative neoplasm, MPN, JAK2 V617F mutation, NQ01 C609T gene polymorphism parça uzunluk çeşitliliği yöntemi kullanılarak tayin edildi. İstatistiksel analizlerde SPSS 21.0 paket programı kullanıldı.

Bulgular: Hasta ve kontrol grubu arasında NQ01 genotip dağılımları açısından istatistiksel olarak anlamlı fark bulunmamıştır $(p>0,05)$. ET, PMF ve PV tanılı olgular JAK2 V617F mutasyonunun sıklığı açısından karşılaștırıldığı zaman PV'deki oran daha yüksek saptanmıștır (sırasıyla; \%62,5, \%61,5, \%78,6). JAK2 mutasyonu pozitifliği ile NQ01*2 polimorfizmi arasında ilișki saptanmamıștır.

Sonuç: Çalıșmamızdan elde ettiğimiz sonuçlara göre, NQ01*2 polimorfizmi ile MPN arasında ilişki bulunmamaktadır. Prokarsinojenlerin detoksifikasyonu ve aktivasyonu için gerekli olan NQ01 enziminin varyantları, MPN hastalarında yaygın olan JAK2 V617F mutasyonunun oluşumunu artırmamıștır. Sonuçların hasta ve kontrol grubu sayısının artırılmasıyla desteklenmesi gerektiği düșünülmektedir.

Anahtar Kelimeler: Miyeloproliferatif neoplazi, MPN, JAK2 V617F mutasyonu, NQ01 C609T gen polimorfizmi

\section{Introduction}

Philadelphia-negative (Ph-) myeloproliferative neoplasms (MPNs) are a group of clonal multipotential hematopoietic stem cell diseases characterized by overproduction of mature and fully functional blood cells in one or more cell types, as well as thrombotic events and leukemia transformation. They consist mainly of polycythemia vera (PV), essential thrombocythemia (ET) and primary myelofibrosis (PMF) (1).

Our knowledge of the pathogenesis of MPNs has been dramatically expanded since the janus kinase 2 (JAK2) V617F mutation was discovered in 2005. In the period after the JAK2 V617F mutation was found, more critical fundamental deviations were identified, such as repetitive changes in the thrombopoietin receptor (MPL) gene, exon 12 mutations in the JAK2 gene, and finally different types of mutations in the calreticulin gene. Advanced studies have shown that the JAK2 V617F mutation is higher than 95\% in PV and approximately $50-60 \%$ in ET or PMF (2-4).

The JAK2 V617F mutation, the somatic single-point mutation in the JAK2 gene in patients with myeloproliferative neoplasia, is a tyrosine kinase mutation, and this mutation occurs in $50-95 \%$ of Ph- MPN cases (5). In 2006, mutations in the $515^{\text {th }}$ codon of MPL were identified in 3-8\% of cases diagnosed with ET and PMF (6). In 2007, an additional mutation was identified in JAK2 exon 12 in several cases with PV that did not carry the JAK2 V617F allele (7). All of these mutant alleles cause the gain of function due to the activation of tyrosine kinase-dependent cellular signal pathways, especially the JAK-STAT pathway (8). However, activation in the JAK-STAT pathway has also been proven in cases that do not carry the JAK2 or MPL mutation. This evidence indicates that there are still unknown mutations in other genes associated with this pathway, and this is still of great interest to researchers. Also, the cellular and molecular mechanisms involved in the pathophysiology of MPNs have not been fully elucidated yet. Although these mutations cannot fully explain the phenotypic heterogeneity of MPNs, further genetic changes still await identification in approximately $20 \%$ of ET and PMF cases $(7,8)$.
The detoxification enzyme NAD(P)H quinone oxidoreductase 1 (NQO1) is a phase 1 enzyme expressed in a wide range of tissue, including the bone marrow in the human body, including the epithelium of various organs. The most important feature of this enzyme is to prevent the formation of reactive and toxic semiquinone intermediate metabolites by reducing two electrons in a single step (9). NQ01 protects cells from free radicals and toxic oxygen metabolites from single-electron reductions catalyzed by cytochrome P450 and other enzymes (10). Also, NQ01 has been shown to play a direct role in protecting against oxidative stress by preventing the redox cycle and free radical formation (11). There are more than 93 single nucleotide polymorphisms (SNPS) discovered in the NQ01 gene located on the chromosome in 16q22.1. A change in the amino acid sequence of the protein occurs with the C/T change (C609T) (rs1800566) at position 609, the most studied SNP of the NQ01 CDNA encoding the NQ01 enzyme (P187S) (10). Compared to the original type, heterozygous individuals (C/T or NQ01*1/*2) have intermediate activity, while homozygotes (T/T or NQ01*2/*2) are insufficient in NQ01 activity (12). In the presence of this polymorphism, the enzyme's ability to detoxify carcinogens is reduced, which may increase the likelihood of malignant changes in susceptible individuals.

Described as an anti-cancer enzyme, NQ01 plays a protective role in carcinogenesis by modifying internal exposure to bioactive carcinogens. In some studies, NQ01 C609T polymorphism has been associated with the risk of childhood and adult acute lymphoblastic leukemia (ALL) and acute myeloid leukemia (AML) (13-16).

Based on all this information, in our study, we aimed to investigate whether there is a relationship between NQ01 C609T polymorphism and MPN development.

\section{Methods}

The study included 119 patients (64 ET, 13 PMF, and 42 PV) who were diagnosed at the İstanbul University İstanbul Faculty of Medicine, Department of Hematology between 1995-2013 and met the 2008 "World Health Organization (WHO)" criteria (17) and 122 healthy controls. The control group consisted of volunteers without hematological 
malignancy in their family and with a mean age similar to the patient group. In this study, which was accepted by the Ethics Committee of İstanbul University İstanbul Faculty of Medicine (decision no: 2012/6341037), an informed consent form was obtained from the subjects before the study. The study was supported by the İstanbul University Scientific Research Fund (project no: BAP/23924). DNA was isolated from the peripheral blood samples with two cc EDTA taken from patients during their routine check-ups between 2012 and 2013 (MagnaPure Compact DNA Isolation Kit, Roche). JAK2 V617F mutation was determined using real-time-polymerase chain reaction (RT-PCR), and NQO1*2 gene polymorphism was determined using PCR -restriction fragment length polymorphism method.

\section{JAK-2 V617F Real-time-Polymerase Chain Reaction Analysis}

The JAK2 V617F assay was performed using the manufacturer's recommended protocol ("JAK2 MutaScreenTM Kit Reference scale" Ipsogen, Luminy Biotech, Marseille, France).

\section{NQ01 Gene Region Analysis}

For NQ01 gene region

Forward primer: 5'AGTGGCATTCTGCATTTCTGTG-3',

Reverse primer: 5'-GATGGACTTGCCCAAGTGATG-3',

PCR protocol: Following the initial denaturation at $94{ }^{\circ} \mathrm{C}$ for 2 minutes; 35 cycles including 45 seconds denaturation at $94^{\circ} \mathrm{C}, 45$ seconds binding at $58{ }^{\circ} \mathrm{C}$, 45 seconds elongation at $72{ }^{\circ} \mathrm{C}$, and finally 5 minutes at $72{ }^{\circ} \mathrm{C}(18)$. Genotyping was performed by imaging the obtained PCR products at 37 ${ }^{\circ} \mathrm{C}$ with Hinf1 restriction enzyme and imaging under UV in 2\% agarose gel.

\section{Statistical Analysis}

The results obtained from the patient and control groups were statistically evaluated with SPSS 21.0 program (SPSS Inc., Chicago, IL, USA). The differences of the parametric data between the two groups were evaluated with the Student's t-test, and the parametric differences between the three groups were evaluated by one-way analysis of variance. The rates were compared with the chi-square test. The results are shown as mean \pm standard deviation (SD). The 95\% confidence interval, odds ratio, and $p$ value were determined. Results with a $p$ value of $<0.05$ were considered significant. Fisher's exact test was used when the minimum expected value (MEV) was $\leq 5$, and Pearson's chi-square was used when MEV was $\geq 25$.

\section{Results}

Our study cohort included a total of 119 MPN patients, including 64 MP, 13 PMF, and 42 PV patients, and 119 healthy controls. One of our ET patients (CC genotype) and one of our PMF patients (CT genotype) had AML transformation. Clinical information of our patient group is given in Table 1. The mean age of diagnosis of the patients was 55.44 (SD: 14.25), and the age of the patients was higher in the PMF group than the ET group $(p<0.05)$. Blood samples were taken for a mean of 6.18 (SD: 5.66$)$ years after the diagnosis. The mean leukocyte count of patients was 10.99x10\%/L (SD: 5.61), Hemoglobin (Hb) level was 14.34 g/dL (SD: 3.42), platelet count was $744.07 \times 10^{9} / \mathrm{L}$ (SD: 421.25), and LDH level was 511.27 U/L (SD: 264.97). Leukocyte count was statistically significantly higher in the PMF group and PV group than in the ET group $(p<0.001$ and $p=0.014$, respectively). $\mathrm{Hb}$ level was higher in the ET group than the PMF group $(p<0.001)$ and was significantly higher in the PV group than ET

\begin{tabular}{|c|c|c|c|c|}
\hline & ET & PMF & PV & Total \\
\hline n (\%) & $64(53.80 \%)$ & $13(10.90 \%)$ & $42(35.30 \%)$ & $119(100 \%)$ \\
\hline Female (\%) & $27(42.19 \%)$ & $8(61.54)$ & $20(47.62 \%)$ & $55(46.22 \%)$ \\
\hline Male (\%) & $37(57.81 \%)$ & $5(38.46 \%)$ & $22(52.38 \%)$ & $64(53.78 \%)$ \\
\hline Leukocyte (X109/L) (mean \pm SD) & $9.65 \pm 4.26$ & $14.24 \pm 9.35^{b}$ & $12.30 \pm 4.89^{c}$ & $10.99 \pm 5.60$ \\
\hline $\mathrm{Hb}(\mathrm{g} / \mathrm{dL})(\mathrm{X} \pm \mathrm{SD})($ mean $\pm \mathrm{SD})$ & $13.63 \pm 2.02^{b}$ & $10.66 \pm 2.40$ & $17.79 \pm 3.39^{b}$ & $14.34 \pm 3.42$ \\
\hline Platelet (X10 $/ \mathrm{L})($ mean $\pm \mathrm{SD})$ & $931.66 \pm 372.93^{b}$ & $551.44 \pm 430.27$ & $436.34 \pm 274.93$ & $744.07 \pm 421.25$ \\
\hline $\mathrm{LDH}(\mathrm{U} / \mathrm{L})($ mean $\pm \mathrm{SD})$ & $421.76 \pm 181.68$ & $776.00 \pm 392.16$ & $566.80 \pm 244.93$ & $511.27 \pm 264.97$ \\
\hline Bone marrow reticulin fibrous degree & $100 \%$ & $100 \%$ & $100 \%$ & $100 \%$ \\
\hline 0 & $20.93 \%$ & 0 & $4.54 \%$ & $12.90 \%$ \\
\hline 1 & $58.14 \%$ & 0 & $54.56 \%$ & $48.10 \%$ \\
\hline 2 & $20.93 \%$ & $8.33 \%$ & $18.18 \%$ & $18.20 \%$ \\
\hline 3 & 0 & $75 \%$ & $18.18 \%$ & $16.90 \%$ \\
\hline 4 & 0 & $16.67 \%$ & $4.54 \%$ & $3.90 \%$ \\
\hline Use of hydroxyurea (\%) & $82.80 \%$ & $76.90 \%$ & $76.20 \%$ & $79.80 \%$ \\
\hline
\end{tabular}


and PMF groups $(p<0.001)$. Platelet count was statistically significantly higher in the ET group than PMF and PV groups ( $p<0.001$ and $p<0.001$, respectively). Reticulin fibrosis levels were higher in the PMF group than in ET and PV groups. It was observed that reticulin fibrosis levels were increased in ascending order in ET, PV, and PMF groups, respectively. When the PMF group was compared with the ET group, the frequency of splenomegaly was observed to be at high frequency (Fischer's exact test, $p<0.001)$. All PMF patients had splenomegaly. The frequency of splenomegaly was higher in the PV group than in the ET group (Pearson $\left.X^{2}=11.291 ; p<0.001\right)$. There was no difference between the patient groups in terms of hydroxyurea use $(p>0.05)$. JAK2 V617 mutations were detected in 40 (62.5\%) ET patients, 8 (61.5\%) PMF patients and 33 (78.6\%) PV patients (Table 2). Although JAK2 mutation was higher in the PV group than the PMF group, no significant difference was observed $(p=0.08)$. JAK2 V617 mutation distribution was similar between PV and ET and PMF and ET patient groups ( $p>0.05)$.

In the statistical evaluation, no relation was found between the presence of splenomegaly and the patient subgroups in terms of the presence of the JAK2 mutation. When NQO1 genotype distribution was examined, rapid metabolizer CC genotype was observed in $42 \mathrm{ET}$ patients (65.6\%), 9 PMF (69.2\%) patients, and 25 PV (59.5\%) patients. Intermediate metabolizer CT genotype was detected in 20 ET (31.3\%) patients, four PMF (30.8\%) patients and 12 PV (28.6\%) patients. The slow metabolizer TT genotype was observed in two ET (3.1\%) patients and five PV (11.9\%) patients but was not found in PMF patients. When the patients were compared in terms of $\mathrm{NQO}^{*} 2$ polymorphism, no difference was observed between the ET, PMF, and PV groups in terms of genotypes ( $p>0.05)$. CC genotype was observed in $85(69.7 \%)$ controls. CT genotype was found in 35 (28.7\%) controls, and the TT genotype was found in two (1.6\%) controls. When the entire patient group and the control group were examined in terms of genotype distributions, there was no statistically significant difference $(p>0.05$ ) (Table 3$)$. In the entire patient group and patient subgroups, it was observed that NQ01 alleles were not related to age, gender, disease duration, leukocyte, platelet, $\mathrm{Hb}$, and bone marrow reticulin fibrosis levels $(\mathrm{p}>0.05)$. In the PV group, the platelet count was significantly higher in those carrying the NQ01 T allele $(p=0.047)$. No difference was observed in other patient subgroups.

According to the distribution of NQ01 polymorphism in patient subgroups and total patient group, the presence of JAK2 mutation was examined (Table 4). In terms of the co-existence of NQO1 polymorphism and JAK2 mutation, the patient and control groups were similar $(p>0.05)$. No difference was observed among the patient subgroups ( $p>0.05)$.

\section{Discussion}

Classic Ph- MPNs are a family of clonal chronic hematological malignancies, including PV, ET, and PMF (19). Transformation of

Table 2. JAK2 V617F mutation distribution of patients diagnosed with essential thrombocythemia, primary myelofibrosis, and polycythemia vera

\begin{tabular}{|l|l|l|l|l|}
\hline & ET, $\mathbf{n}(\%)$ & PMF, $\mathbf{n}(\%)$ & PV, $\mathbf{n}(\%)$ & Total, $\mathbf{n}(\%)$ \\
\hline JAK2 V617F Mutation & & & \\
\hline Yes & $40(62.5 \%)$ & $8(61.5 \%)$ & $33(78.6 \%)$ & $81(68.1 \%)$ \\
\hline No & $24(37.5 \%)$ & $5(38.5 \%)$ & $9(21.4 \%)$ & $38(31.9 \%)$ \\
\hline
\end{tabular}

ET: essential thrombocythemia, PMF: primary myelofibrosis, PV: polycythemia vera, JAK2: janus kinase 2

Table 3. Distribution of $\mathrm{NAD}(\mathrm{P}) \mathrm{H}$ quinone oxidoreductase-1 $(\mathrm{C}>\mathrm{T})$ polymorphism genotypes between patient and control groups

\begin{tabular}{|c|c|c|c|c|c|}
\hline \multirow{2}{*}{ Genotype } & \multicolumn{4}{|c|}{ MPN group $(n=119)$} & \multirow{2}{*}{ Control group $(n=122$} \\
\hline & ET $(n=64)$ & $\operatorname{PMF}(n=13)$ & $P V(n=42)$ & Total $(n=119)$ & \\
\hline $\mathrm{RM}(\mathrm{CC})$ & $42(65.6 \%)$ & $9(69.2 \%)$ & $25(59.5 \%)$ & $76(63.9 \%)$ & $85(69.7 \%)$ \\
\hline $\mathrm{IM}(\mathrm{CT})$ & $20(31.3 \%)$ & $4(30.8 \%)$ & $12(28.6 \%)$ & $36(30.2 \%)$ & $35(28.7 \%)$ \\
\hline SM (TT) & $2(3.1 \%)$ & $0(0 \%)$ & $5(11.9 \%)$ & $7(5.9 \%)$ & $2(1.6 \%)$ \\
\hline
\end{tabular}

MPN: myeloproliferative neoplasm, ET: essential thrombocythemia, PMF: primary myelofibrosis, PV: polycythemia vera, RM: Rapid metabolizer, IM: intermediate metabolizer, SM: slow metabolizer

Table 4. Relationship between NAD(P)H quinone oxidoreductase-1 (C>T) polymorphism and JAK2 V617F mutation in patient groups

\begin{tabular}{|c|c|c|c|c|}
\hline \multirow{2}{*}{\multicolumn{2}{|c|}{$\mathrm{NQ01}(\mathrm{C}>\mathrm{T})$}} & \multicolumn{2}{|c|}{ JAK2 V617F mutation } & \multirow{2}{*}{ Total, n (\%) } \\
\hline & & $(+)$ n (\%) & $(-)$ n (\%) & \\
\hline \multirow{2}{*}{ ET } & $\mathrm{CC}$ & $17(70.8 \%)$ & $25(62.5 \%)$ & $42(65.6 \%)$ \\
\hline & $\mathrm{CT}+\mathrm{TT}$ & $7(29.2 \%)$ & $15(37.5 \%)$ & $22(34.4 \%)$ \\
\hline \multirow{2}{*}{ PMF } & $\mathrm{CC}$ & $2(40 \%)$ & $7(87.5 \%)$ & $9(69.2 \%)$ \\
\hline & $\mathrm{CT}+\mathrm{TT}$ & $3(60 \%)$ & $1(12.5 \%)$ & $4(30.8 \%)$ \\
\hline \multirow{2}{*}{ PV } & $\mathrm{CC}$ & $5(55.6 \%)$ & $20(60.6 \%)$ & $25(59.5 \%)$ \\
\hline & $\mathrm{CT}+\mathrm{TT}$ & $4(44.4 \%)$ & 13(39.4\%) & $17(40.5 \%)$ \\
\hline \multirow{2}{*}{ Total } & $\mathrm{CC}$ & $24(63.2 \%)$ & $52(64.2 \%)$ & $76(63.9 \%)$ \\
\hline & $\mathrm{CT}+\mathrm{TT}$ & $14(36.8 \%)$ & $29(35.8 \%)$ & $43(36.1 \%)$ \\
\hline
\end{tabular}

NQ01: NAD(P)H quinone oxidoreductase-1, JAK2: janus kinase 2, ET: essential thrombocythemia, PV: polycythemia vera, PMF: primary myelofibrosis 
MPNs into AML is characterized by a $20 \%$ blast in the bone marrow or peripheral blood, according to the WHO, and is one of the most feared complications of MPN. Approximately 5-10\% of all MPNs progress to AML within ten years after diagnosis, which occurs in 1\% of ET cases, $4 \%$ of PV cases, and $20 \%$ of PMF cases. Although the risk factors leading to this transformation have not been entirely determined, advanced age ( $>60$ years) and exposure to chemotherapy are known to increase the risk of transformation. The molecular basis of this progression has not yet been clarified and remains attractive as a current research area $(20,21)$.

In our study, it was aimed to investigate the prevalence of NQ01 C609T polymorphism, which causes loss of enzyme activity and which may be a risk factor in the etiology of specific hematopoietic malignancies in the Turkish community of MPN patients.

In NQ01 gene defective mice, the increase in myeloid cells in the peripheral blood, bone marrow, and granulocytes significantly causes myeloid cell hyperplasia (22). NQ01-/-g-radiation mice have also been shown to develop the myeloproliferative disease, including loss of spleen follicular structure and bone marrow hypercellularity due to the infestation of granulocytes and megakaryocytes in the blood granulocytes and bone marrow myeloid cells. These results provide direct evidence that mice with NQ01 deficiency are highly prone to developing the myeloproliferative disease (23). The association between NQ01 C609T polymorphism and the risk of acute leukemia has been reported from the studies conducted since 2000, but these data are still insufficient. In their study with 82 patients with different types of hematopoietic malignancies and 99 healthy controls in 2011, Lozic et al. (24) reported that NQ01 C609T polymorphism was more common in adult patients with myeloid disorder compared to adult controls ( $p=0.0267)$. The results of the meta-analysis study conducted by Cuiping Li and Yang Zhou (25). in 2014 show that NQ01 C609T polymorphism is a significant genetic risk factor in ALL. As a result of another meta-analysis study, NQ01 C609T polymorphism was found to be associated with increased ALL risk (26). According to the study results of Ouerhani et al. (27), the NQ01 C609T polymorphism has been reported concerning the increased risk of ALL in the Tunisian population. According to the results of Smith et al. (28), null or low NQ01 activity caused by the inheritance of the C609T allele has been reported to be associated with an increased risk of de novo acute leukemia in adults. It has also been reported that there is a statistically significant relationship between NQ01 C609T polymorphism and the risk of chronic myelocytic leukemia (29).

As a result, in most of the studies, NQ01 C609T polymorphism has been associated with increased hematopoietic malignancies. However, the data of the only study conducted by Sirma et al. (30) in the Turkish population on this issue provide evidence that the NQ01 C609T polymorphism does not play a role in the etiology of de novo pediatric acute leukemia. We think that these different results between studies may result from differences in ethnic origin and sample sizes.

\section{Conclusion}

Our study is the first study to examine the relationship between NQ01 C609T polymorphism and MPN in the Turkish population. Our results are that there is no relationship between NQ01*2 polymorphism and MPN.
It is also inferred that the NQ01 enzyme variants, which are important in the activation of detoxification and procarcinogens, do not increase the formation of the JAK2 V617F mutation, which is common in MPN patients. We think that the results should be supported by increasing the number of patient and control groups.

Ethics Committee Approval: In this study, which was accepted by the Ethics Committee of İstanbul University İstanbul Faculty of Medicine (decision no: 2012/634-1037).

Informed Consent: Informed consent form was obtained from the subjects before the study.

Peer-review: Externally peer-reviewed.

Author Contributions: Design - A.B.A.T., A.D.A.; Data Collection and/ or Processing - A.B.A.T., A.D.A., H.D., I.Y.H., O.Ö., A.S.Y.; Analysis and/or Interpretation - H.Y.A.; Literature Search - A.B.A.T.; Writing Manuscript A.B.A.T., A.D.A.

Conflict of Interest: No conflict of interest was declared by the authors.

Financial Disclosure: The study was supported by the İstanbul University Scientific Research Fund (project no: BAP/23924).

\section{References}

1. Barbui T, Thiele J, Gisslinger H, Finazzi G, Vannucchi AM, Tefferi A. The revision of WHO classification of myeloproliferative neoplasms: clinical and molecular advances, Blood Rev 2016; 30: 453-59.

2. Guglielmelli P, Barosi G, Specchia G, Rambaldi A, Lo Coco F, Antonioli E, et al Identification of patients with poorer survival in primary myelofibrosis based on the burden of JAK2V617F mutated allele. Blood 2009; 114: 1477-83.

3. Tefferi A, Lasho TL, Huang J, Finke C, Mesa RA, Li CY, et al. Low JAK2V617F allele burden in primary myelofibrosis, compared to either a higher allele burden or unmutated status, is associated with inferior overall and leukemiafree survival. Leukemia 2008; 22: 756-61.

4. Barosi G, Bergamaschi G, Marchetti M, Vannucchi AM, Guglielmelli P, Antonioli E, et al. Gruppo Italiano Malattie Ematologiche Maligne dell'Adulto (GIMEMA) Italian Registry of Myelofibrosis. JAK2 V617F mutational status predicts progression to large splenomegaly and leukemic transformation in primary myelofibrosis. Blood 2007; 110: 4030-6.

5. Campbell PJ, Baxter EJ, Beer PA, Scott LM, Bench AJ, Huntly BJ. Et al. Mutation of JAK2 in the myeloproliferative disorders: Timing, clonality studies, cytogenetic associations, and role in leukemic transformation. Blood 2006;108:3548-55.

6. Pikman Y, Lee BH, Mercher T, McDowell E, Ebert BL, Gozo M, et al. MPLW515L is a novel somatic activating mutation in myelofibrosis with myeloid metaplasia. PLoS Med 2006; 3: e270.

7. Pardanani AD, Levine RL, Lasho T, Pikman Y, Mesa RA, Wadleigh M, et al MPL515 mutations in myeloproliferative and other myeloid disorders: A study of 1182 patients. Blood 2006; 108: 3472-76.

8. Scott LM, Tong W, Levine RL, Scott MA, Beer PA, Stratton MR, et al. JAK2 exon 12 mutations in polycythemia vera and idiopathic erythrocytosis. N Engl J Med 2007; 356: 459-68.

9. Strassburg A, Strassburg CP, Manns MP, Tukey RH. Differential gene expression of $\mathrm{NAD}(\mathrm{P}) \mathrm{H}$ :quinone oxidoreductase and $\mathrm{NRH}$ : quinone oxidoreductase in human hepatocellular and biliary tissue. Mol Pharmacol 2002; 61: 320-5.

10. Nebert DW, Roe AL, Vandale SE, Bingham E, Oakley GG. NAD(P)H:quinone oxidoreductase (NQ01) polymorphism, exposure to benzene, and predisposition to disease: A HuGE review. Genet Med 2002; 4: 62-70. 
11. Siegel D, Gustafson DL, Dehn DL, Han JY, Boonchoong P, Berliner LJ, et al. $\mathrm{NAD}(\mathrm{P}) \mathrm{H}$ : quinone oxidoreductase 1 : role as a superoxide scavenger. Mol Pharmacol 2004; 65: 1238-47.

12. Moran JL, Siegel D, Ross D. A potential mechanism underlying the increased susceptibility of individuals with a polymorphism in $\mathrm{NAD}(\mathrm{P}) \mathrm{H}$ :quinone oxidoreductase 1 (NQ01) to benzene toxicity. Proc Natl Acad Sci USA 1999; 96: 8150-5.

13. Naoe T, Takeyama K, Yokozawa T, Kiyoi H, Seto M, Uike N, et al. Analysis of genetic polymorphism in NQ01, GST-M1, GST-T1, and CYP3A4 in 469 Japanese patients with therapy-related leukemia/ myelodysplastic syndrome and de novo acute myeloid leukemia. Clin Cancer Res 2000; 6: 4091-95.

14. Smith MT, Wang Y, Kane E, Rollinson S, Wiemels JL, Roman E, et al. Low NAD(P) $\mathrm{H}$ : quinone oxidoreductase 1 activity is associated with increased risk of acute leukemia in adults. Blood 2001; 97: 1422.

15. Smith MT, Wang Y, Skibola CF, Slater DJ, Lo Nigro L, Nowell PC, et al. Low $\operatorname{NAD}(\mathrm{P}) \mathrm{H}$ : quinone oxidoreductase activity is associated with increased risk of leukemia with MLL translocations in infants and children. Blood 2002; 100: 4590-93.

16. Krajinovic M, Sinnett H, Richer C, Labuda D, Sinnett D. Role of NQ01, MPO and CYP2E1 genetic polymorphisms in the susceptibility to childhood acute lymphoblastic leukemia. Int J Cancer 2002; 97: 230-6.

17. Tefferi A, Vardiman JW. Classification and diagnosis of myeloproliferative neoplasms: The 2008 World Health Organization criteria and point-of-care diagnostic algorithms. Leukemia. 2008; 22(1):14-22.

18. Ouerhani S, Cherif N, Bahri I, Safra I, Menif S, Abbes S. Genetic polymorphisms of NQ01, CYP1A1 and TPMT and susceptibility to acute lymphoblastic leukemia in a Tunisian population. Mol Biol Rep 2013; 40: 1307-14.

19. Boddu P, Masarova L, Verstovsek S, Strati P, Kantarjian H, Cortes J, et al. Patient characteristics and outcomes in adolescents and young adults with classical Philadelphia chromosome-negative myeloproliferative neoplasms. Ann Hematol 2018; 97: 109-11.

20. Kundranda MN, Tibes R, Mesa RA. Transformation of a chronic myeloproliferative neoplasm to acute myelogenous leukemia: Does anything work? Curr Hematol Malig Rep 2012; 7: 78-86.
21. Finazzi G, Caruso V, Marchioli R, Capnist G, Chisesi T, Finelli C, et al. ECLAP Investigators. Acute leukemia in polycythemia vera: An analysis of 1638 patients enrolled in a prospective observational study. Blood 2005; 105: 266470

22. Bauer AK, Faiola B, Abernethy DJ, Marchan R, Pluta LJ, Wong VA, et al. Genetic susceptibility to benzene-induced toxicity: Role of NADPH:quinone oxidoreductase-1. Cancer Res 2003; 63: 929-35.

23. Iskander K, Barrios RJ, Jaiswal AK. Disruption of $N A D(P) H: Q u i n o n e$ oxidoreductase 1 gene in mice leads to radiation-induced myeloproliferative disease. Cancer Res 2008; 68: 7915-22.

24. Lozic B, Primorac D, Glavinic R, Samija RK, Zemunik T. Analysis of the C609T polymorphism of NQ01 gene in South Croatian patients with hematological malignancies. Coll Antropol 2011; 35: 385-88.

25. Li C, Zhou Y. Association between NQ01 C609T polymorphism and acute lymphoblastic leukemia risk: Evidence from an updated meta-analysis based on 17 case-control studies. J Cancer Res Clin Oncol 2014; 140: 873-81.

26. He H, Zhai X, Liu X, Zheng J, Zhai Y, Gao F, et al. Associations of NQ01 C609T and NQ01 C465T polymorphisms with acute leukemia risk: A PRISMAcompliant meta-analysis. Onco Targets Ther 2017; 10: 1793-801.

27. Ouerhani S, Cherif N, Bahri I, Safra I, Menif S, Abbes S. Genetic polymorphisms of NQ01, CYP1A1 and TPMT and susceptibility to acute lymphoblastic leukemia in a Tunisian population. Mol Biol Rep 2013; 40: 1307-14.

28. Smith MT, Wang Y, Kane E, Rollinson S, Wiemels JL, Roman E, et al. Low NAD(P) $\mathrm{H}$ :quinone oxidoreductase 1 activity is associated with increased risk of acute leukemia in adults. Blood 2001; 97: 1422-6.

29. Hishida A, Terakura S, Emi N, Yamamoto K, Murata M, Nishio K, et al. GSTT1 and GSTM1 Deletions, NQ01 C609T Polymorphism and Risk of Chronic Myelogenous Leukemia in Japanese. Asian Pacific J Cancer Prev 2005; 6: 2515.

30. Sirma S, Agaoglu L, Yildiz I, Cayli D, Horgusluoglu E, Anak S, et al. NAD(P) H:Quinone Oxidoreductase 1 Null Genotype Is not Associated With Pediatric De Novo Acute Leukemia. Pediatr Blood Cancer 2004; 43: 568-70. 